\title{
Chapter 5 \\ Life Cycle Sustainability Assessment: A Tool for Exercising Due Diligence in Life Cycle Management
}

\author{
Bernard Mazijn and Jean-Pierre Revéret
}

\begin{abstract}
Starting from the output 'The Future We Want' of the Rio+20 conference 2012, the main focus of this chapter is on social responsibility (SR) in the value chain. The historical context of SR is discussed, related to the international standards as are the Guidance on Social Responsibility and the Global Reporting Initiative, linked with the management of organizations and enterprises. It is emphasized that due diligence along the value chain is seen as a requirement for claiming 'social responsibility'. Life cycle sustainability assessment (LCSA) contributes to the assessment and life cycle management (LCM) to the follow-up of exercising due diligence, all within the context of sustainable development. The over-arching LCSA is a combination of three different life cycle assessment techniques allowing to assess the impacts along the value chain: environmental LCA, social LCA and life cycle costing.
\end{abstract}

Keywords Life cycle assessment $\bullet$ Life cycle management $\bullet$ Life cycle sustainability assessment $\bullet$ Life cycle thinking $\bullet$ Rio+20 conference $\bullet$ Social responsibility

\section{Introduction}

The Rio+20 conference (2012) addressed the themes of 'a green economy in the context of sustainable development and poverty eradication', and of 'the institutional framework for sustainable development' as referred to in the output of the conference titled The Future We Want (UN 2012a, b).

\footnotetext{
B. Mazijn ( $\square)$

Ghent University and IDO vzw, p/a Michel Van Hammestraat 76, 8310 Bruges, Belgium e-mail: bernard.mazijn@ugent.be

J.-P. Revéret

CIRAIG - Université du Québec à Montréal,

Case postale 8888, succ. Centre-Ville, Montréal H3C 3P8, QC, Canada

(C) The Author(s) 2015

G. Sonnemann, M. Margni (eds.), Life Cycle Management,

LCA Compendium - The Complete World of Life Cycle Assessment,

DOI 10.1007/978-94-017-7221-1_5
} 
The adoption of the 10-year framework of programs on sustainable consumption and production patterns was confirmed. In the additional document (UN 2012c), several functions are listed to be included, amongst others "Promoting the engagement of the private sector in efforts to achieve a shift towards sustainable consumption and production, particularly sectors with a high environmental and social impact, including through corporate environmental and social responsibility."

Furthermore, the resolution itself is explicit on "renewing political commitment" and calls for the engagement of major groups and other stakeholders, inter alia the private sector. Therefore, the General Assembly of the United Nations states, e.g.: "We support national regulatory and policy frameworks that enable business and industry to advance sustainable development initiatives, taking into account the importance of corporate social responsibility. We call upon the private sector to engage in responsible business practices..."

\section{Taking Up Social Responsibility in the Value Chain}

\subsection{About Social Responsibility of Organizations}

\subsubsection{Historical Context}

The modern concept of corporate social responsibility (CSR), born in the USA, has developed over more than the last century. It can be traced back in a series of business practices in the late nineteenth century such as the philanthropy of some particularly rich capitalists and its development into a doctrine during the twentieth century that began to be theorized in the 1950s (Pasquero 2013). Many authors agree that the book by H. Bowen in 1953 'Social Responsibilities of the Businessman' is the seminal contribution to this field that has shaped its development for several decades. He offers an initial definition that reads: "Social responsibility refers to the obligations of the businessman to pursue those policies, to make those decisions, or to follow those lines of action which are desirable in terms of the objectives and values of our society." (Bowen 1953). During the sixties and seventies, there was a proliferation of definitions which built on Bowen's work. Joseph W. McGuire (1963) brought some more precise elements about the extension of the responsibility by writing "The idea of social responsibility supposes that the corporation has not only economic and legal obligations but also certain responsibilities to society which extend beyond these obligations." (McGuire 1963). However, these new visions of the role of businessmen were strongly challenged by liberal thinkers such as Milton Friedman, see his paper in the New York Times Magazine (1970) "A Friedman doctrine - The social responsibility of business is to increase its profits" (Friedmann 1970). This illustrates rather clearly the opposition between the fundamental vision of neoclassical economics, where business corporations contribute to the general interest, and the new managerial vision developed through CSR, where business has also a social and/or societal mission. The stakeholder theory, initially developed by Freeman (1984), had the ambition to provide managers with a 
conceptualization of the civil society and a theoretical model of the company and social actors, even if it did not really work to explain the social dynamics in place (Gendron 2013).

The development of CSR was strongly reinforced with the emergence of the concept of "sustainable development" and the international summits that followed the publication of the Brundtland Report in 1987, starting with the Rio summit in 1992. It is now a well-established field of research, of teaching in universities and of actions in companies. Nowadays as Capron (2013) suggests, implementing CSR and practices that contribute to sustainable development is usually presented as an approach derived from a strategic decision by the company to answer societal expectations but also, and especially in the European Union, more and more as a way to insert companies into national strategies defined by public authorities.

\subsubsection{International Standards}

Over the years CSR has been defined in different ways. Dalhsrud (2008) concluded from his analysis that "the existing definitions are to a large degree congruent", and "the confusion is not so much about how CSR is defined, as about how CSR is socially constructed in a specific context".

"A specific context" is determined to a large extent by the stakeholders which are an important dimension when taking up corporate social responsibility. Therefore, it could be expected that definitions of CSR at the international level are co-designed in a process involving stakeholders.

The overview of Dahlsrud could not yet take into account the final version of ISO 26000 - Guidance on social responsibility (2010) -, but the process behind did fulfil the "requirement" of co-design. It can be observed that the international standard has "social responsibility" in its title without reference to corporations or enterprises. The reason is "The view that social responsibility is applicable to all organizations emerged as different types of organizations, not just those in the business world, recognized that they too had responsibilities for contributing to sustainable development." Under the "Terms and definitions", "organization" is defined as "entity or group of people and facilities with an arrangement of responsibilities, authorities and relationships and identifiable objectives".

The widely accepted definition of ISO 26000 on social responsibility goes as follows "responsibility of an organization for the impacts of its decisions and activities on society and the environment, through transparent and ethical behaviour that

- contributes to sustainable development, including health and the welfare of society;

- takes into account the expectations of stakeholders;

- is in compliance with applicable law and consistent with international norms of behaviour; and

- is integrated throughout the organization and practised in its relationships."

It is noted in ISO 26000 that "activities include products, services and processes" and "relationships refer to an organization's activities within its sphere of influence". 
Furthermore, to define the scope of social responsibility, seven core subjects are identified: organizational governance, human rights, labour practices, the environment, fair operating practices, consumer issues and community involvement and development. Each core subject includes a range of relevant issues.

There are three other leading international initiatives that are contributing to the uptake of social responsibility in business:

- The UN Global Compact is an initiative that started in 1999 and it can be seen as "a strategic policy initiative for businesses that are committed to aligning their operations and strategies with ten universally accepted principles in the areas of human rights, labour, environment and anti-corruption". ${ }^{1}$ Networks of businesses that have committed to respect the ten principles and work extensively on capacity building among the enterprises have been set up at the international and national level. The last revision took place in 2010.

- The Global Reporting Initiative (GRI) is a multi-stakeholder initiative that was launched in 1997 by the Coalition for Environmentally Responsible Economies (CERES) and the United Nations Environment Programme (UNEP). ${ }^{2}$ The GRI Guidelines are developed as a sustainability reporting framework that standardizes enterprises' reports on environmental, social and economic dimensions. For each dimension, performance indicators are formulated covering similar concerns as the issues of ISO 26000 (GRI 2011). The fourth revision of the guidelines has been launched in May 2013.

- The OECD Guidelines for Multinational Enterprises, one element of the OECD Declaration on International Investment and Multinational Enterprises, are "recommendations on responsible business conduct addressed by governments to multinational enterprises operating in or from adhering countries". ${ }^{3}$ The latest revision of the guidelines was conducted in 2011.

These international initiatives, including their revisions over the years, illustrate the importance given to the uptake of social responsibility. However, the question arises if by these guiding initiatives enterprises are stimulated to develop a systematic and coherent due diligence approach in their corporate strategy regarding the value chain.

\subsection{Linking with Management}

With a long history behind, a stronger legitimacy and a set of structuring frameworks, CSR has now a clear role in the sphere of management. This appears in practice more rapidly and efficiently in sectors where it "fits" naturally with a set of

\footnotetext{
${ }^{1}$ See http://www.unglobalcompact.org/AboutTheGC/ (last accessed February 2015).

${ }^{2}$ See https://www.globalreporting.org/ (last accessed February 2015).

${ }^{3}$ See http://www.oecd.org/daf/internationalinvestment/guidelinesformultinationalenterprises/ (last accessed February 2015).
} 
values that characterizes the domain. This is the case of "social economy" and cooperatives where the notion of social utility is already present. They are a fertile ground for placing CSR and related tools at a central place in the company's management strategy. The same holds true for the socially responsible investment sector. It is also a fact that large corporations are more prone to adopt CSR and adjust their management accordingly than small enterprises.

From a managerial perspective, CSR is the company's response to societal interpellations by producing different strategies, management tools, methods of control, evaluation and reporting. This implies that the company deals with societal issues such as public health, security, environment, which usually belong to the public sphere and therefore call for a political democratic debate (Capron and Quairel-Lanoizelée 2012). It therefore creates a kind of positive competition between companies and the State to produce public values (Bozeman 2007). The company will have to operationalize the concept of stakeholders and know their stakeholders through a mapping exercise. They will have to consider the conditions of production not only on their sites but also with their suppliers. This is why supply chain management often starts through the adoption of a responsible procurement strategy, one of the fast developing new management tools.

As there is a clear obligation of transparency, societal reporting has become a public objective that constraints companies to develop measuring tools for the social and environmental impacts of their activities. The numerous new standards and labels analyzed above are becoming new management tools to certify certain characteristics of products or processes that allow to act on different dimensions of production, in different parts of the world, through economics.

\subsection{About "Due Diligence"}

"Due diligence" is defined as a "comprehensive, proactive process to identify the actual and potential negative social, environmental and economic impacts of an organization's decisions and activities over the entire life cycle of a project or organizational activity, with the aim of avoiding and mitigating negative impacts" (ISO 2010). Another important consideration relates to "rule of law" versus "international norms of behaviour", mentioned as one of the points of attention in the ISO 26000-definition: "An organization should respect international norms of behaviour, while adhering to the principle of respect for the rule of law" (ISO 2010). In the international standard, this principle is linked with the notion of "complicity", indicating that this has both legal and non-legal meanings: "In this context, an organization may be considered complicit when it assists in the commission of wrongful acts of others that are inconsistent with, or disrespectful of, international norms of behaviour that the organization, through exercising due diligence, knew or should have known would lead to substantial negative impacts on society, the economy or the environment. An organization may also be considered complicit where it stays 
silent about or benefits from such wrongful acts." Furthermore, note that three forms of complicity can be described (ISO 2010):

- Direct complicity, when organizations (incl. enterprises) knowingly assist in the commission of wrongful acts

- Beneficial complicity, when organizations (incl. enterprises) benefit directly from these wrongful acts committed by someone else

- Silent complicity, when this involves the failure by an organization to raise with the appropriate authorities the question of systematic or continuous wrongful acts

It is not surprising that in the ISO 26000 these three forms are related and exemplified with the avoidance of human rights violation.

From these considerations, it is clear that "due diligence" is indeed "a comprehensive, proactive process" for an organizations' governance in addressing the issues of social responsibility.

In the Implementation Manual of the GRI Sustainability Reporting Guidelines, the notion of "due diligence" is used the first time as part of the "governance" requirements: "Report the highest governance body's role in the identification and management of economic, environmental and social impacts, risks, and opportunities. Include the highest governance body's role in the implementation of due diligence processes."

For the purposes of the OECD Guidelines for Multinational Enterprises, "due diligence is understood as the process through which enterprises can identify, prevent, mitigate and account for how they address their actual and potential adverse impacts as an integral part of business decision-making and risk management systems." In the paragraphs related to the General Policies, it is stressed that "enterprises should" "avoid causing or contributing to adverse impacts on matters covered by the Guidelines, through their own activities, and address such impacts when they occur". The Commentary on the General Policies is explicit on stressing that "own activities includes their activities in the supply chain". Furthermore, a Deming wheel approach is strongly recommended: "In the context of its supply chain, if the enterprise identifies a risk of causing an adverse impact, then it should take the necessary steps to cease or prevent that impact." However "The Guidelines recognise that there are practical limitations on the ability of enterprises to effect change in the behaviour of their suppliers." Note that this is very much related to the sphere of influence mentioned above.

For UN Global Compact "due diligence" is in the first place related to the human rights principles where "identifying and managing human rights risk will help business respect human rights and avoid complicity in human rights abuse". ${ }^{4}$ The concept of "sphere of influence" has been introduced as well and is seen to "help map the scope of a company's opportunities to support human rights and make the greatest positive impact". But it is recognized: "While these opportunities may be

\footnotetext{
${ }^{4}$ See http://www.unglobalcompact.org/Issues/human_rights/The_UN_SRSG_and_the_UN_ Global_Compact.html (last accessed February 2015).
} 
greatest with respect to a company's own operations and workers, the ability to act gradually declines as consideration moves outward to the supply chain, to local communities, and beyond." Therefore, UN GC is developing further guidance on how to take a more proactive approach to integrate the Global Compact principles into supply chain management practices. Supply chain sustainability is an important work stream of UN GC.

\subsection{Due Diligence: Assessment Through LCSA?}

Referring to the expectations of stakeholders when taking up social responsibility, exercising due diligence means an identification of "the actual and potential negative social, environmental and economic impacts of an organization's decisions and activities over the entire life cycle of a project or organizational activity"5 (ISO 26000). The following questions arise: (1) what does it mean actual and potential negative social, environmental and economic impacts"? and (2) how can "the entire life cycle of a project or organizational activity" be described?

\subsubsection{The Social, Environmental and Economic Impacts}

The reason for societal concerns about the social, environmental and economic impacts is because of the externalities produced by "activities that affect the wellbeing of people or damage the environment, where those impacts are not reflected in market prices. The costs (or benefits) associated with externalities do not enter standard cost accounting schemes" (Valdivia et al. 2011). Figure 5.1 shows a matrix illustrating the distinction between private costs and externalities and reflecting what is at stake when assessing the value chain producing goods or services within the context of sustainable development. "An externality occurs when a decision within the value chain imposes costs or benefits on others which are not reflected in the prices charged for the goods and services being provided by the value chain. Externalities are sometimes referred to as spill overs. An externality may also result in private costs, even though it might not be accounted for in the decision-making" (Benoit and Mazijn 2009).

The solid black line in Fig. 5.1 delimits the private costs and benefits reflected in the market price. Sometimes external relevant costs and benefits anticipated to be privatized, such as increasing prices of $\mathrm{CO}_{2}$ emissions, are taking into account in monetary terms: see dashed line. However, it is illusory to think one can reflect all

\footnotetext{
${ }^{5}$ This is a quote coming from ISO 26000 . Note that 'life cycle sustainability assessment' tries to provide a more comprehensive picture of the positive and negative impacts along the product life cycle. However, this is as such not contradictory because in terms management ISO 26000 recommends: "An organization can exercise its influence with others either to enhance positive impacts on sustainable development, or to minimize negative impacts, or both".
} 


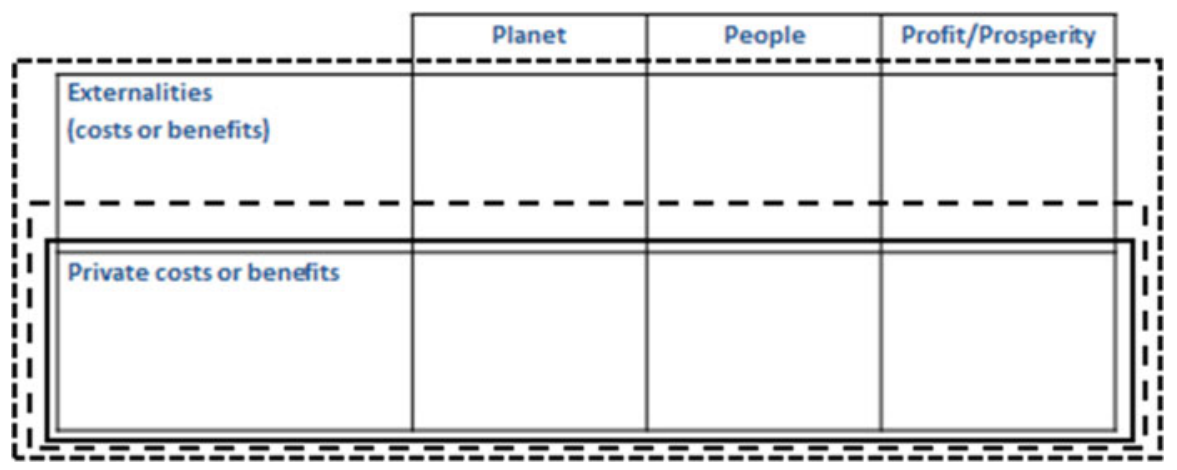

Fig. 5.1 Detailing the assessment of the value chain producing goods and services within the context of sustainable development ${ }^{6}$

externalities, within the limits of the dotted line, in the costs of goods and services produced by the value chain. ${ }^{7}$ Therefore other indicators to take social, environmental and economic impacts into account - "in consistency with international norms of behaviour" (cf. CSR definition of ISO 26000) - are needed. In fact, the purpose is to detail the already mentioned seven core subjects of social responsibility.

\subsubsection{Life Cycle Sustainability Assessment}

The reference to "the entire life cycle" in ISO 26000 is linked to "a project or organizational activity" and as has been noted "activities include products, services and processes". In fact, this is closely connected with what has been phrased in Agenda 21 - Chapter 4 to "develop criteria and methodologies for the assessment of environmental impacts and resource requirements throughout the full life cycle of products and processes". ${ }^{8}$ Later on, this "life cycle thinking" was explained as follows by UNEP: "Life Cycle Thinking is about understanding environmental, social and economic impacts into people's hands at the time they are making decisions. It offers a way of incorporating sustainability in decision making processes and can be used by decision makers in both the public and private sector for the development

\footnotetext{
${ }^{6}$ Note that making a distinction between the three dimensions of sustainable development (environment, economy and society) is often referred to as the "triple bottom line" concept (TBL) as coined by John Elkington in his 1997 book Cannibals with Forks: The Triple Bottom Line of Twenty-First Century Business, a concept which can be seen as similar to the 3P approach: people, planet and profit. However, since people and planet imply a collective interest, profit can be interpreted as private interest. Therefore, it is not surprising that the World Summit on Sustainable Development, Johannesburg 2002, referred instead to "people, planet and prosperity".

${ }^{7}$ The reason for stating this is related to the problems of having a scientific method of calculating the price at each stage of the value chain, being accepted by all stakeholders.

${ }^{8}$ See http://sustainabledevelopment.un.org/content/documents/Agenda21.pdf (last accessed February 2015).
} 
of policies and products, as well as for procurement and the provision of services." It has been the start at the time of the United Nations Conference on Environment and Development, Rio de Janeiro 1992, for a comprehensive effort to present 20 years later a tool for life cycle sustainability assessment (LCSA).

The precursor of "life cycle assessment (LCA)" goes back to the late 1960s. The development of the technique throughout the 1970s and 1980s was stimulated by eager enterprises and policy makers who wanted to have a better understanding of the environmental impact of packaging and energy content of products. Later on, LCA was applied to an increasing variety of product types, and methods for life cycle environmental impact assessment began to be developed. It resulted initially in the publication of the "Code of Practice" (Consoli et al. 1993), followed by the development of four ISO standards (ISO 14040-14043) published in 1997-2000, all of which were replaced in 2006 by two standards, ISO 14040 and ISO 14044 (ISO ISO 2006a, b). These standards describe the requirements and formulate recommendations for elaborating an LCA. At first it was meant to address the environmental aspects of a product and their potential impacts throughout that product's life cycle. However, the picture is not complete within a context of sustainable development unless social and socio-economic impacts on all actors along the life cycle, including workers, local communities, consumers and society, are analyzed. Discussions on how to deal with social and socioeconomic dimensions of products throughout a life cycle started at the end of the

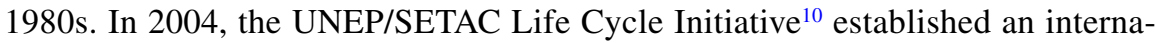
tional Task Force to "to convert the current environmental tool LCA into a triplebottom-line sustainable development tool": by 2009 the "Guidelines for social life cycle assessment of products" were published with a set of (sub-)categories of impacts (Benoit and Mazijn 2009). The subtitle of the publication is relevant within this context: "A social and socio-economic LCA code of practice complementing environmental LCA and Life Cycle Costing, contributing to the full assessment of goods and services within the context of sustainable development." Indeed, LCC or life cycle costing is regarded as the third LCA technique aiming at "the assessment of all costs associated with the life cycle of a product that are directly covered by 1 or more actors in the product life cycle (supplier, manufacturer, user or consumer, and/or End of Life actor), with the inclusion of externalities that are anticipated to be internalized in the decision-relevant future" (Hunkeler et al. 2008).

These different life cycle assessment techniques can be combined as part of an over-arching LCSA and allow to assess the impacts of the value chain. Recently, the methodology has been presented in two publications (Valdivia et al. 2011, 2012) where it is emphasised that LCSA "helps to organise complex environmental, economic and social data in a structured form; clarify the trade-offs between the three sustainability dimensions, life cycle stages and impacts; provide guiding principles

\footnotetext{
${ }^{9}$ See for more information: http://www.lifecycleinitiative.org/starting-life-cycle-thinking/ (last accessed February 2015).

${ }^{10}$ See www.lifecycleinitiative.org (last accessed February 2015).
} 
to achieve sustainable production while stimulating innovation (by identifying weaknesses and enabling further improvements over the product life cycle); help to raise credibility by communicating useful quantitative and qualitative information about their products and process performances (which can also be used to inform labelling initiatives); and show how to become more responsible by taking into account the full spectrum of impacts associated with their products and services. LCSA can support decision-makers in prioritising resources and investments, and in choosing sustainable technologies and products. Finally, LCSA could support consumers in determining which products are cost-efficient; have a low environmental impact and are socially responsible; and, in general, promote awareness in value chain actors on sustainability issues." Note that it is not the aim of assessing in all details the life cycle, but to focus on the so-called "hotspots", i.e. the important impacts. It can be compared with the "materiality" exercise in ISO 26000 in which relevance, significance and priority is looked at in a systematic and coherent manner.

Finally, it is interesting to note that (methodological) developments around "life cycle thinking" were not limited to present tools for analysis or assessment. In fact, LCSA can be regarded as part of the PDCA-cycle ${ }^{11}$ - where the "assessment" correspond clearly with the "check" and should be followed by action (before a renewed planning is set up). This is all about management, i.e. "life cycle management" which is another important area of work over the last 20 years (see e.g. Remmen et al. 2007).

\subsection{Implementation and Follow Up of Due Diligence Through LCM?}

As life cycle management (LCM) is still a domain in development, it is relevant to begin by providing some definitions based on the recent scientific literature.

The SETAC Europe Working Group on LCM defined it as "an integrated framework of concepts, techniques and procedures to address environmental, economic, technological and social aspects of products and organizations to achieve continuous environmental improvement from a life cycle perspective" (Hunkeler et al. 2004). UNEP brings the collaboration and stakeholder perspective, they see LCM "as a product management system aiming to minimize environmental and socioeconomic burdens... during the entire life-cycle...relying on collaboration and communication with all the stakeholders in the value-chain" (Balkau and Sonnemann 2010).

\footnotetext{
${ }^{11}$ PDCA stands for 'Plan, Do, Check, Act' in which 'Check' is sometimes replaced by 'Study' and 'Act' by 'Adjust' (see this volume, Chap. 3).
} 
Obviously definitions vary depending on stakeholders who use or promote it. For this paper, the authors refer to the definition by Balkau and Sonnemann (2010) who see LCM "as an umbrella framework for combining and applying other management instruments in a more holistic life chain perspective".

They offer a classification of LCM approaches into three broad categories:

(1) Organization of a holistic form of sustainability management within individual companies using, for example, supply-chain management and product design (Five Winds International 2009)

(2) Government life-cycle policies and regulations to address system dysfunctions or to deal with certain product issues such as chemical contamination.

(3) Multi-stakeholder voluntary codes to manage sustainability issues for selected commodity materials and products.

Nilsson-Linden et al. (2014) provide an interesting view into the theoretical aspects of LCM and LCM in practice. For them "the review of the LCM literature indicates that it provides many normative prescriptions of what LCM is, including what tools, methods, and approaches to use". But they also tell us that in fact this literature indicates in fact what ought to be considered, but without providing compelling descriptions and analysis of the difficulties involved in organising LCM in practice. This is a common critique about the state of development of LCM.

However, the authors consider LCM as the most appropriate framework to integrate and organize adequately the large tool box that was developed piece by piece without a pre-existing integrating framework to contribute to CSR and sustainable development in a coherent and consistent manner.

Taking up social responsibility is much more than caring for the environment. At least six other core subjects such as human rights, labour practices, etc. are important as well. Therefore, it is fair to state that CSR should be framed within the broader context of sustainable development. Furthermore, the social responsibility is not limited to the management of the facility or plant of an enterprise; "due diligence" should be exercised all along the value chain. In other words, if it is not part of the corporate strategy, an enterprise may be considered complicit because it does not cope with the broad societal expectations of behaviour. But due diligence is a process and it needs frameworks and tools.

Our pieces come together here. CSR through ISO 26000 and through its links with sustainable development calls the organization to consider upstream and downstream of its activities and to look for aspects that were not even monitored recently by traditional organisations. One needs for that a perspective that is multidimensional and along the life cycle of a product or service: this is called life cycle thinking.

Life cycle sustainability assessment, taking into account the three dimensions of sustainable development, and using a toolbox of different techniques, will provide the enterprise with the analysis and the evaluation of the impacts along the value chain. It forms in its turn an input for life cycle management. 


\section{Outlook}

To paraphrase Nilsson-Linden et al. (2014): "many normative prescriptions of what LCM is, indicate in fact what ought to be considered, including what tools, methods, and approaches to use". Indeed further research is needed at several levels.

The authors are confident that organizations should not wait to take up social responsibility by using the approach as outlined here above. However, they consider that there are needs for research and practice, inter alia:

- Collaboration between the world of (C)SR and LC(S)A: researchers and practitioners should learn to interact with each other, in particular on the issues "materiality", "due diligence", "value chain", "life cycle"

- Streamlining of the approach of "due diligence" in the different international standards (ISO 26000, GRI, OECD MNE Guidelines, UN GC)

- Incorporation of stakeholder involvement practice in (C)SR into LCSA and LCM

- (Better) integration of three LCA-techniques under the over-arching LCSA; details regarding methodological issues have already been identified: see e.g. Benoit and Mazijn (2009) and Valdivia et al. (2011)

- Design LCSA for due diligence within the context of social responsibility of (different) organizations (incl. enterprises)

- Implementation of LCM in various realities considering this adoption as a strategic change in management

It should be emphasized that this list is not exhaustive and that progress can be based on research as well as best practices. The Social LC Alliance (www.socialLCA.org), in which the authors take part, aims to contribute in meeting these challenges.

Open Access This chapter is distributed under the terms of the Creative Commons Attribution Noncommercial License, which permits any noncommercial use, distribution, and reproduction in any medium, provided the original author(s) and source are credited.

\section{References}

Balkau F, Sonnemann G (2010) Managing sustainability performance through the value chain, Corporate Governance. Int J Bus Soc 10(1):46-58

Benoît C, Mazijn B (eds) (2009) Guidelines for social life cycle assessment of products - a social and socio-economic LCA code of practice complementing environmental LCA and life cycle costing, contributing to the full assessment of goods and services within the context of sustainable development. UNEP-DTIE, Paris

Bowen HR (1953) Social responsibilities of the businessman. Harper and Brothers, New York

Bozeman B (2007) La publicitude normative: comment conciliar valeurs publiques et valeurs du marché. Politiques et Management Public 24(4):179-196

Capron M (2013) La RSE: Un danger ou un atout pour la démocratie. In: Gendron C, Girard B (eds) Repenser la responsabilité sociale de l'entreprise. L'école de Montréal, Armand Colin Recherches, Paris, pp 123-134

Capron M, Quairel-Lanoizelée F (2012) La responsabilité sociale d'entreprise, Coll. 'Repères. La découverte, Paris 
Consoli F, Allen D, Boustead I, Fava J, Franklin W, Jensen AA, de Oude N, Parrish R, Perriman R, Postlethwaite D, Quay B, Seguin J, Vigon B (1993) Guidelines for life-cycle assessment: a 'Code of Practice'. SETAC, Brussels/Pensacola

Dahlsrud A (2008) How corporate social responsibility is defined: an analysis of 37 definitions. Corp Soc Responsib Environ Manage 15(1):1-13

Friedman M (1970) A Friedman doctrine - The social responsibility of business is to increase its profits. New York Times Magazine, 13 Sept 1970

Freeman RE (1984) Strategic management: a stakeholder approach. Pitman, Boston

Gendron C (2013) La firme: portrait d'un objet ambigu. In: Gendron C, Girard B (eds) Repenser la responsabilité sociale de l'entreprise, Armand Colin Recherches. L'école de Montréal, Paris, pp 135-148

GRI (2011) GRI and ISO 26000: how to use the GRI Guidelines in conjunction with ISO 26000. Global Reporting Initiative, Amsterdam

Hunkeler D, Saur K, Rebitzer G, Finkbeiner M, Schmidth W-P, Jensen A, Stranddorf H, Christiansen K (2004) Life cycle management. SETAC, Pensacola FL

Hunkeler D, Lichtenvort K, Rebitzer G (eds) (2008) Environmental life cycle costing. SETAC Press/Taylor \& Francis Group, New York

ISO (2006a) ISO 14040 - environmental management - life cycle assessment -principles and framework. International Organization of Standardization, Geneva

ISO (2006b) ISO 14044 - environmental management - life cycle assessment - requirements and guidelines. International Organization of Standardization, Geneva

ISO (2010) ISO 26000 - Guidance on social responsibility. International Organisation for Standardisation Geneva

McGuire J (1963) Business and society. McGraw-Hill, New York

Nilsson-Lindén H, Baumann H, Rosén M, Diedrich A (2014) Organizing life cycle management in practice: challenges of a multinational manufacturing corporation. Int J Life Cycle Assess. doi:10.1007/s11367-014-0818-y

Pasquero J (2013) La responsabilité sociale de l'entreprise: trajectoire d'une idée. In: Gendron C, Girard B (eds) Repenser la responsabilité sociale de l'entreprise. L'école de Montréal, Armand Colin Recherches, Paris, pp 47-62

Remmen A, Jensen A, Frydendal J (2007) Life cycle management - a business guide to sustainability. UNEP-DTIE, Paris

UN (2012a) Report of the United Nations conference on sustainable development - Rio de Janeiro, Brazil 20-22 June 2012. Document nr. A/CONF.216/16, United Nations, New York

UN (2012b) Resolution adopted by the General Assembly - The future we want. Document nr. A/ RES/66/288UN General Assembly, New York

UN (2012c) A 10-year framework of programmes on sustainable consumption and production patterns. Document nr. A/CONF.216/5, United Nations, Rio de Janeiro

Valdivia S, Ugaya C, Sonnemann G, Hildebrand J (eds) (2011) Towards a life cycle sustainability assessment - making informed choices on products. UNEP-DTIE, Paris

Valdivia S, Ugaya C, Hildenbrand J, Traverso M, Mazijn B, Sonnemann G (2012) A UNEP/ SETAC approach towards a life cycle sustainability assessment - our contribution to Rio+20. Springer, Int J Life Cycle Assess, November 2012, online 